Article

\title{
Type 2 Diabetes Alters Vascular Cannabinoid Receptor 1 Expression, Phosphorylation Status, and Vasorelaxation in Rat Aorta
}

\author{
Enrique Sánchez-Pastor ${ }^{1}{ }^{\circledR}$, Xóchitl Trujillo ${ }^{1}{ }^{\complement}$, Christian Ramos-Flores ${ }^{1,2}$, Mónica Ríos-Silva ${ }^{1,+}$, \\ Felipa Andrade ${ }^{3}$, Yolitzy Cárdenas ${ }^{1}$, Elena Castro ${ }^{1}$, Zorayda Urzúa ${ }^{4}$, Oscar Newton-Sánchez ${ }^{5}$ \\ and Miguel Huerta $1, * \mathbb{D}$ \\ 1 Enrico Stefani Research Unit, University Center for Biomedical Research, University of Colima, Colima CP \\ 28045, Mexico; espastor@ucol.mx (E.S.-P.); rosio@ucol.mx (X.T.); hugo.ramosf@imss.gob.mx (C.R.-F.); \\ mrios@ucol.mx (M.R.-S.); rosa_cardenas@ucol.mx (Y.C.); ecastro@ucol.mx (E.C.) \\ 2 Mexican Institute of Social Security, Family Medicine Unit \#168, Tepatitlan de Morelos, Jalisco CP 47600, \\ Mexico \\ 3 National Technological Institute of Mexico/Technological Institute of Colima, Avenida Tecnológico No. 1, \\ Villa de Álvarez, Colima CP 28976, Mexico; felipa.andrade@colima.tecnm.mx \\ 4 Mexican Institute of Social Security, Family Medicine Unit \#17, Manzanillo, Colima CP 28219, Mexico; \\ zorayda_urzua@ucol.mx \\ 5 Faculty of Medicine, University of Colima, Colima CP 28040, Mexico; onewton@ucol.mx \\ * Correspondence: huertam@ucol.mx; Tel./Fax: +52-31-23-16-1129 \\ + Cátedras CONACYT-University of Colima.
}

Received: 19 September 2020; Accepted: 20 October 2020; Published: 26 October 2020

\begin{abstract}
Previous studies have suggested a role of the endocannabinoid system in metabolic diseases, such as diabetes. We investigated the effect of diabetes on cannabinoid receptor type 1 $\left(\mathrm{CB}_{1}\right)$ expression and cannabinoid-induced vasorelaxation in rat aorta rings. Aortas from healthy rats and from rats with experimentally induced diabetes were used to compare the vasorelaxant effect of the cannabinoid agonist arachidonylcyclopropylamide (ACPA) and $\mathrm{CB}_{1}$ expression and localization. After 4-8 weeks of diabetes induction, $\mathrm{CB}_{1}$ receptor expression and $\mathrm{CB}_{1}$ phosphorylation were higher in aortic rings, in association with greater vasorelaxation induced by the $\mathrm{CB}_{1}$ agonist $\mathrm{ACPA}$ compared to healthy rats. The vasorelaxant effect observed in healthy rats is similar throughout the study. Further studies are needed to elucidate the implications of $\mathrm{CB}_{1}$ receptor overexpression in diabetes and its influence on the progression of the cardiovascular complications of this metabolic disease.
\end{abstract}

Keywords: cannabinoid; diabetes; $\mathrm{CB}_{1}$ receptor expression; vasorelaxation; $\mathrm{CNR} 1$

\section{Introduction}

Type 2 diabetes mellitus is one of the most prevalent metabolic disorders worldwide. The endocannabinoid system participates in the control of energy homeostasis [1]. Previous findings indicate that the endocannabinoid system plays a critical role in gene expression of cannabinoid receptor type $1\left(\mathrm{CB}_{1}\right.$; also known as $\left.\mathrm{CNR} 1\right)$ in the $\beta$ pancreatic islets and other tissues [2], suggesting a role of the endocannabinoid system in some metabolic diseases, such as type 2 diabetes mellitus. Thus, substances that activate or antagonize $\mathrm{CB}_{1}$ could also affect diabetes endpoints. In addition, elevated glucose increases $\mathrm{CB}_{1}$ expression in the kidney, pancreas, subcutaneous adipose tissue and nervous system [2-5]. Regarding cardiovascular effects, the $\mathrm{CB}_{1}$ and cannabinoid receptor type 2 $\left(\mathrm{CB}_{2}\right)$ agonist WIN 55,212-2 elicits vasorelaxation in rat aorta [6]. However, the effect of the activation of these receptors on type 2 diabetes mellitus has not been elucidated. As we reported recently [7], 
pre-incubation of rat aortic rings with the $\mathrm{CB}_{1}$ agonist arachidonylcyclopropylamide (ACPA) results in vasorelaxation. This vasorelaxant effect is completely blocked by the $\mathrm{CB}_{1}$ antagonist AM281, suggesting a role of $\mathrm{CB}_{1}$ activation in the regulation of vascular tone.

Taken together, these findings suggest a dual role of $\mathrm{CB}_{1}$ in both glucose regulation and vaso-responsiveness, depending on the activation or inhibition of the receptor. The aim of the present study was to evaluate whether diabetes alters the vasorelaxant effects of the $\mathrm{CB}_{1}$ agonist $\mathrm{ACPA}$ in aortic rings and $\mathrm{CB}_{1}$ receptor expression or phosphorylation in the aorta.

\section{Results}

\subsection{Body Weight and Serum Glucose}

Bodyweight and fasting glucose were measured before and at 2, 4, and 8 weeks after the initiation of experimental diabetes (Table 1). After 4 and 8 weeks, the weight of the diabetic rats was decreased compared to their initial weight; diabetic rats had elevated fasting glucose levels compared to their initial levels and with respect to control rats (Table 1 ).

Table 1. Bodyweight and serum glucose levels in rats.

\begin{tabular}{lcccccc}
\hline & \multicolumn{2}{c}{ 2 Weeks } & \multicolumn{2}{c}{ 4 Weeks } & \multicolumn{2}{c}{ 8 Weeks } \\
\cline { 2 - 6 } & Initial & Final & Initial & Final & Initial & Final \\
\hline Healthy & $279 \pm 3.84$ & $322 \pm 8.23 *$ & $319 \pm 14.4$ & $338 \pm 4.85$ & $321 \pm 6.69$ & $342 \pm 8.71 *$ \\
Diabetes & $235 \pm 9.3$ & $263 \pm 10.8^{*}$ & $280 \pm 8.16$ & $243 \pm 9.9$ & $308 \pm 13.33$ & $275 \pm 14.65$ \\
& \multicolumn{4}{c}{ Fasting Glucose $(m g / d L)$} \\
Healthy & $81 \pm 1.78$ & $85 \pm 2.56$ & $76.80 \pm 2.2$ & $78 \pm 2.21$ & $83 \pm 4.49$ & $77 \pm 1.5$ \\
Diabetes & $319 \pm 19.28$ & $405 \pm 19.83 *$ & $288 \pm 18.46$ & $478 \pm 34.7 *$ & $310 \pm 13.13$ & $441 \pm 13.71$ * \\
\hline
\end{tabular}

Data are presented as mean \pm standard error. ${ }^{*} p<0.05$ Student's $t$-test for paired samples.

\subsection{Effects of Cannabinoids on Vasorelaxation of Aortic Rings from Diabetic and Healthy Rats}

We previously reported that ACPA causes vasorelaxation of aortic rings from healthy rats through activation of $\mathrm{CB}_{1}$, an effect that is blocked when the rings are pre-incubated with the $\mathrm{CB}_{1}$ antagonist AM281 [7]. To explore the effects of $C_{1}$ activation on the vascular tone of aortic rings during the progression of diabetes in rats $\left(2,4\right.$, and 8 weeks), we used ACPA, a selective agonist for $\mathrm{CB}_{1}$. ACPA induced vasorelaxation, reaching a maximum of $20.64 \pm 5.2 \%$ ( $n=4$ rats) and $16.94 \pm 3.84 \%$ ( $n=4$ rats) at two weeks; $17.74 \pm 3.83 \%$ ( $n=5$ rats $)$ and $20.98 \pm 4.56 \%(n=5$ rats $)$ at four weeks; and $20.17 \pm 3.04 \%(n=7$ rats, $p<0.01)$ and $37.87 \pm 5.63 \%$ at eight weeks $(n=7$ rats, $p<0.001$ relative to the control condition; Figure 1A) for healthy and diabetics rats, respectively. We reported previously and corroborated here that the maximum vasorelaxation induced by the same concentration of ACPA in aortic rings from healthy rats was about $20 \%$ throughout the study. Thus, the vasorelaxant effect of the cannabinoid ACPA on aortic rings from diabetic rats in the present study was more pronounced than the slower vasorelaxation effect of ACPA on aortic rings from healthy rats in the previous study. Furthermore, the vasorelaxant effect of ACPA on aortic rings from diabetic rats after eight weeks of diabetes induction was almost completely reversed when the rings were incubated with the $\mathrm{CB}_{1}$ antagonist AM281 30 min previous to the addition of ACPA $(3.86 \pm 1.78 \% ; n=5$ rats). Figure $1 \mathrm{~B}$ shows contractures by phenylephrine and the effect of ACPA on healthy (upper trace) and diabetic rats (lower trace). ACPA induced a more pronounced relaxation in aortic rings from diabetic rats than those from healthy rats. A smaller contracture induced by $1 \mu \mathrm{M}$ Phe was observed in aortic rings from diabetic rats as above described. 


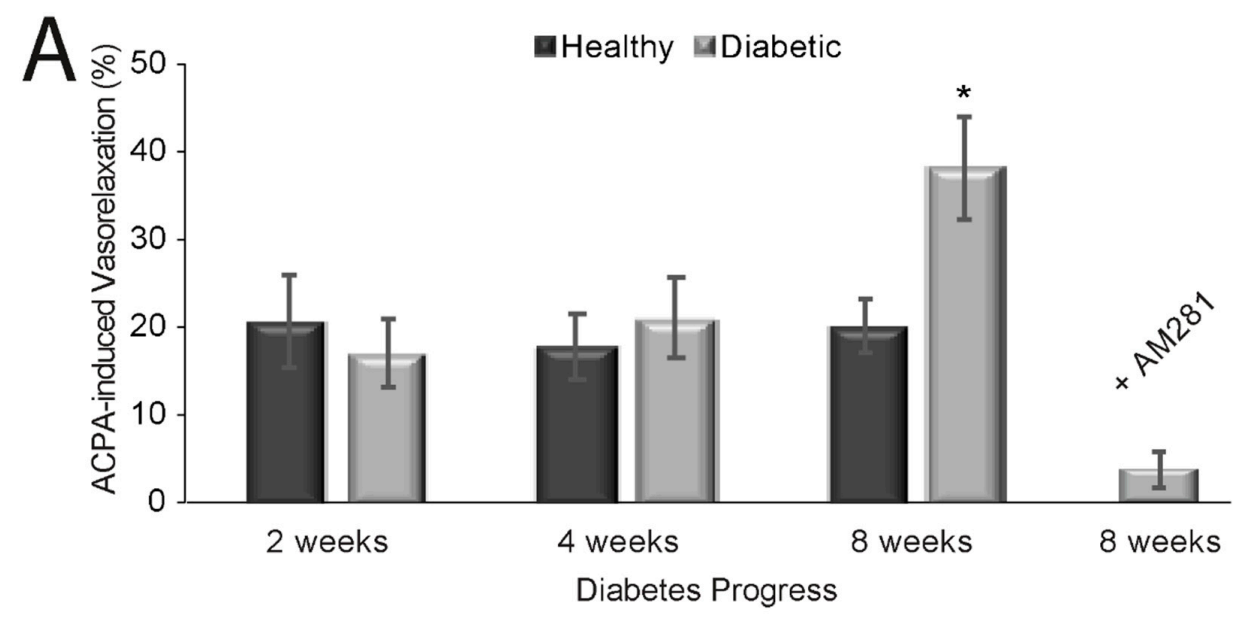

B
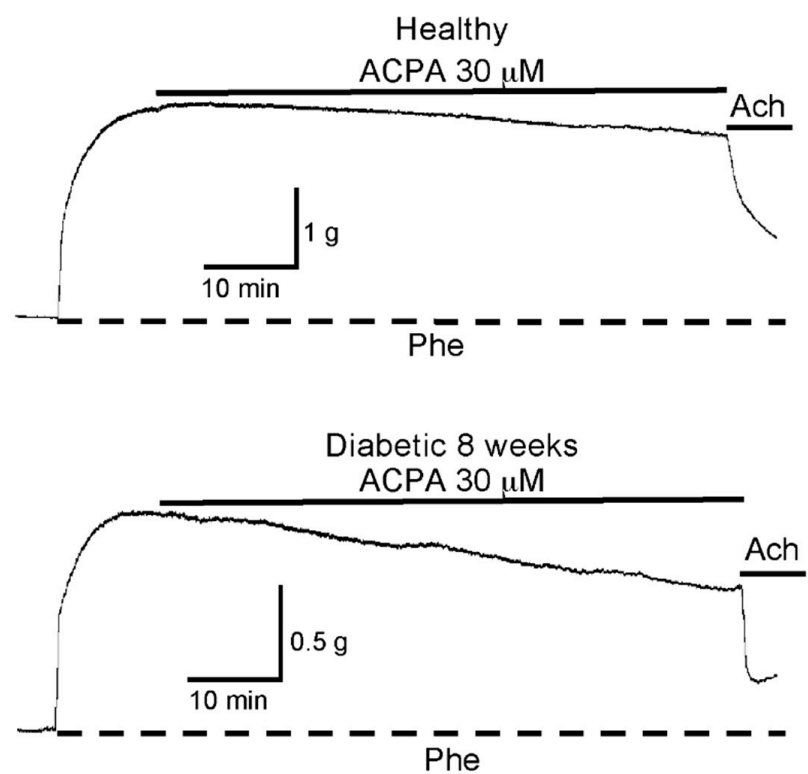

Figure 1. Vasorelaxant effect of arachidonylcyclopropylamide (ACPA) on healthy and diabetic rat aortic rings. (A). Summary of the vasorelaxant effect induced by ACPA at different times after diabetes induction. Dark bars correspond to healthy rats, and gray bars correspond to diabetic rats after 2, 4 or 8 weeks after Streptozotocin administration. The effect of ACPA when cannabinoid receptor type $1\left(\mathrm{CB}_{1}\right)$ receptors were blocked with AM281 is shown in the last gray bar. * Significant $(p<0.05)$ change in tension compared to Phe precontraction. (B) Isometric tension recording of phenylephrine (Phe)-induced contraction of aortic rings. The top lines indicate exposure to ACPA. Upper trace: vasorelaxant effect of ACPA on a healthy ring. Lower trace: effect of ACPA on a diabetic ring. The relaxation of tension was measured at $60 \mathrm{~min}$ of ACPA treatment. The vasorelaxant effect was more pronounced in aortic rings from diabetic rats than those from healthy rats ( $n=5$ rats).

\section{3. $C B_{1}$ Receptor Expression, Phosphorylation Status and Localization in Diabetic Rat Aorta}

To further explore the role of $\mathrm{CB}_{1}$ receptors in diabetes, we explored whether the increased vasorelaxant effect seen in diabetes is related to a modulation of $\mathrm{CB}_{1}$ expression in aortic rings from diabetic rats and/or a change in the phosphorylation status of the receptor. These issues were addressed in immunohistochemistry experiments with an anti- $\mathrm{CB}_{1}$ antibody that labels total $\mathrm{CB}_{1}$ receptors or by labeling only phosphorylated $\mathrm{CB}_{1}$ receptors. The experiments were performed in parallel in aortic rings from healthy and diabetic rats using the same amounts of antibodies and incubation times. Confocal images were acquired using the same parameters. The mean immunofluorescence intensities of total $\mathrm{CB}_{1}$ and phosphorylated $\mathrm{CB}_{1}$ were analyzed at distinct times $(2,4$, and 8 weeks) 
of diabetes progression vs. controls (i.e., healthy rats) as shown in Figure 2. Total $\mathrm{CB}_{1}$ receptors had a mean intensity of $100 \pm 8.03 \%$ and $49.85 \pm 24.72 \%(p=0.04 ; n=4$ rats $)$ after 2 weeks; $100 \pm 4.37 \%$ and $115.68 \pm 11.84 \%(p=0.31 ; n=4$ rats $)$ after 4 weeks; and $100 \pm 6.29 \%$ and $145.83 \pm 10.14 \%(p<0.02$; $n=4$ rats) at 8 weeks for healthy and diabetic rats, respectively. Thus, total $\mathrm{CB}_{1}$ receptor expression is increased in the rat aorta after eight weeks of diabetes induction (Figure 2A). Phosphorylated $\mathrm{CB}_{1}$ receptors had a mean intensity of $100 \pm 5.12 \%$ and $60.29 \pm 2.04 \%(p<0.0001 ; n=4$ rats $)$ at 2 weeks; 100 $\pm 7.07 \%$ and $157.23 \pm 9.89 \%(p=0.006 ; n=4$ rats $)$ at 4 weeks; and $100 \pm 11.06 \%$ and $176.59 \pm 11.20 \%(p=$ $0.01 ; n=4$ rats) at 8 weeks for healthy and diabetic rats, respectively (Figure 2B). A significant increase in the mean intensity of phosphorylated $\mathrm{CB}_{1}$ was observed after four weeks of diabetes progression $(2$ vs. 4 weeks, $p<0.001 ; n=4$ rats). The immunofluorescence did not differ significantly between 4 and 8 weeks.
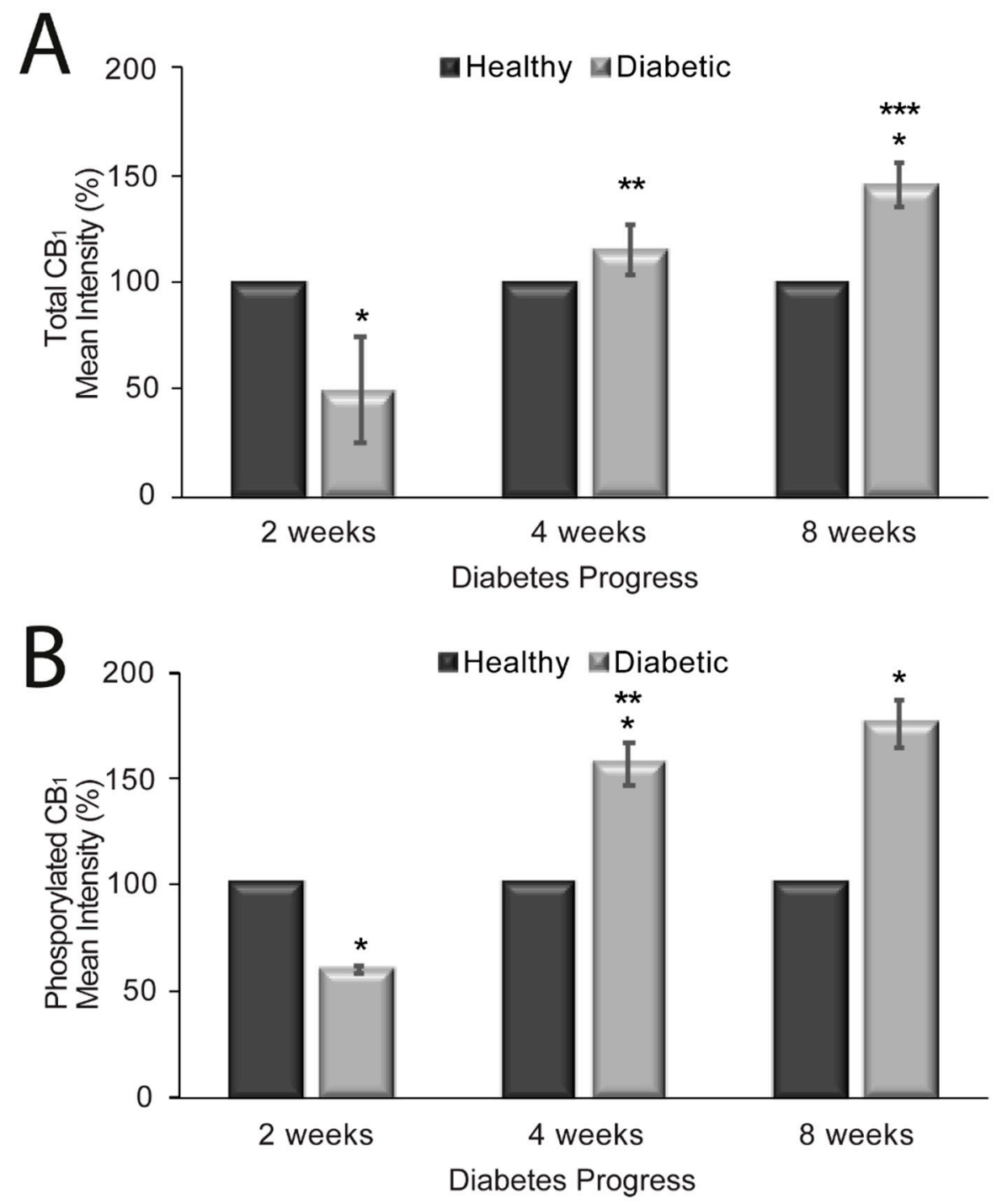

Figure 2. Mean intensity of total $\mathrm{CB}_{1}$ receptors $(\mathrm{A})$ and phosphorylated $\mathrm{CB}_{1}$ receptors $(\mathbf{B})$ in healthy and diabetic rat aortas. $n=10$ image stacks for each. ${ }^{*}$ Significant $(p<0.05)$ change in $\mathrm{CB}_{1}$ mean intensity in diabetic vs. healthy aortic rings at different time points. ${ }^{*}$ Significant difference $(p<0.05)$ in $\mathrm{CB}_{1}$ mean intensity between 2 and 4 weeks. ${ }^{* * *}$ Significant difference $(p<0.05)$ in $\mathrm{CB}_{1}$ mean intensity between 4 and 8 weeks.

Figure 3 shows phosphorylated $\mathrm{CB}_{1}$ receptor labeling in aortas from healthy and diabetic rats eight weeks after diabetes onset. $C_{1}$ is localized in smooth muscle (Figure $\left.3 B, C, F, G\right)$. The intensity of 
the signal was higher in diabetic rings than in healthy rings (compare Figure $3 \mathrm{~A}, \mathrm{E})$. Similar results were obtained when total $\mathrm{CB}_{1}$ receptors were labeled.
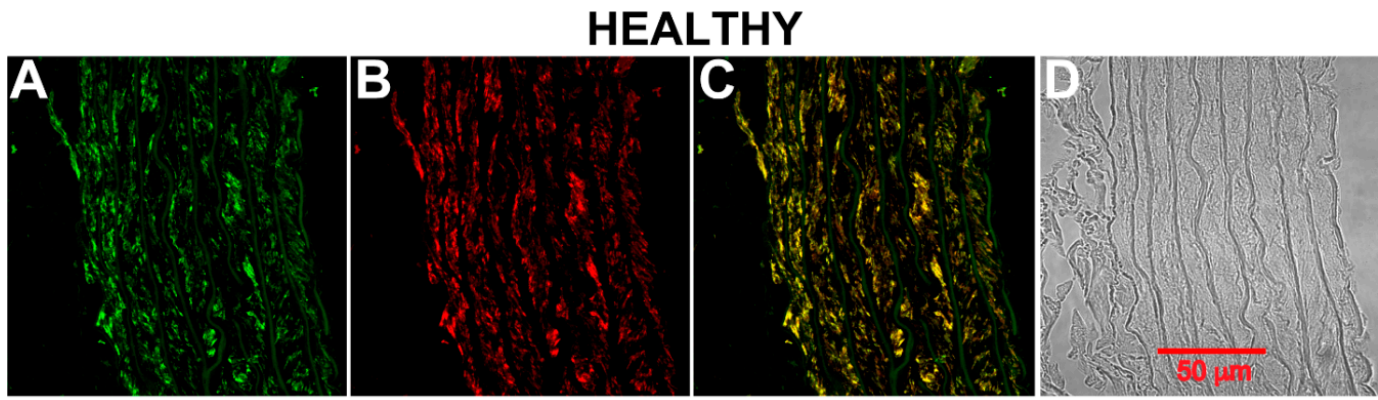

DIABETIC
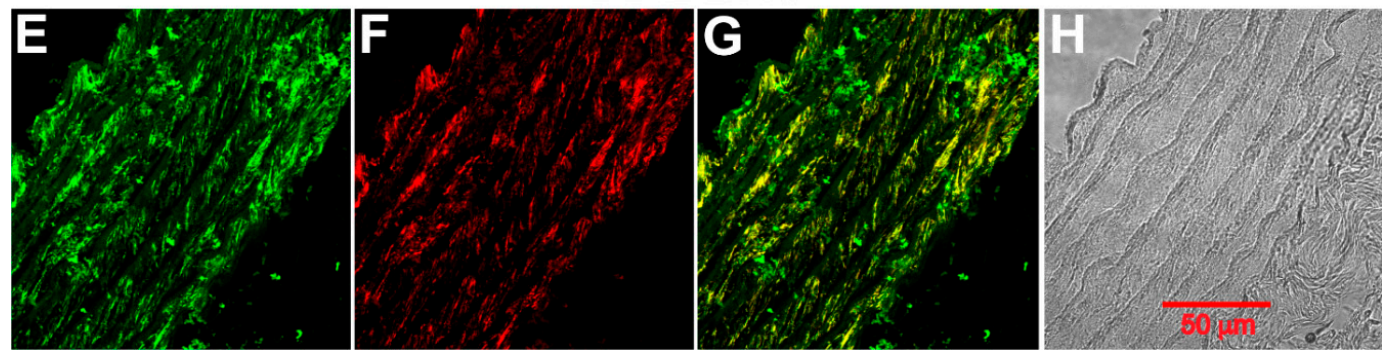

Figure 3. Phosphorylated $\mathrm{CB}_{1}$ receptor on rat aortic smooth muscle. (A) Healthy rat aortic ring showing $\mathrm{CB}_{1}$ receptor (green) and (B) smooth muscle $\alpha$-actin (red). (C) An overlay of (A) and (B). (D) Bright-field microscopy image of the aortic ring. (E) Diabetic rat aortic ring (8 weeks) showing $\mathrm{CB}_{1}$ receptor (green) and (F) smooth muscle $\alpha$-actin (red). (G) An overlay of (E) and (F). (H) Bright-field microscopy image of the aortic ring.

\section{Discussion}

The role of the endocannabinoid system has recently emerged as being important in the pathogenesis of type 2 diabetes mellitus, which is a well-known risk factor for cardiovascular disease and heart failure, though the mechanisms involved are not well-understood [8-11].

Diabetes has been shown to decrease the maximum relaxation and sensitivity to Acetylcholine, with hyperglycemia being the major causal factor in the development of this endothelial dysfunction [12]. Delta-9-tetrahydrocannabinol treatment and some endocannabinoids improve endothelium-dependent relaxation of the aorta in the Zucker rat model of type 2 diabetes, as well as the STZ/nicotinamide-induced diabetic rat model [12-15]. However, vascular endothelium-independent mechanisms have not been studied. Here, we showed that ACPA has an increased vasorelaxant effect on the aorta by direct modulation of $\mathrm{CB}_{1}$ receptors on the artery smooth muscle cells [7].

The aim of the present study was to evaluate the possible changes in the expression of $\mathrm{CB}_{1}$ receptors on thoracic aorta from streptozotocin-induced diabetic rats and its functional role by investigating the in vitro effects of the administration of a cannabinoid $\mathrm{CB}_{1}$ receptor agonist on aortic rings. Recently, evidence has accumulated regarding the vasorelaxant effects of cannabinoids in isolated blood vessel preparations [8,9]. Several studies have reported hypotensive effects of the endocannabinoid anandamide $[13,14]$, and an enhancement of these effects has been shown in hypertensive rats [16-19], as well as increased circulating levels of this endocannabinoid in diabetic patients [20], suggesting that anandamide could have beneficial vascular effects. In 2012, Hopps et al. [21] reported enhanced vasorelaxant effects of oleamide in hypertension and that this increase could be explained by an adaptation to increased blood pressure. However, there have been no reports of the effects of cannabinoids in diabetes. The effects of anandamide reported in these studies were mediated by the activation of both $C_{1}$ and TRPV1 receptors. Thus, we used a potent and selective $\mathrm{CB}_{1}$ receptor agonist to evaluate the effect of the activation of these receptors on the vascular tone of aortas from diabetic 
rats. We recently reported that the $\mathrm{CB}_{1}$ receptor agonist $\mathrm{ACPA}$ induces vasorelaxation of aortic rings from healthy rats, and this effect was mediated by the activation of $\mathrm{CB}_{1}$ receptors, $\mathrm{BK}_{\mathrm{Ca}}{ }^{2+}$ channels, and the inhibition of voltage-gated $\mathrm{Ca}^{2+}$ channels located at the membrane of smooth muscle cells in these arteries [7]. Our results indicate that ACPA has a more pronounced ( 2 times) vasorelaxant effect on aortic rings from diabetic rats at eight weeks than the effect observed in healthy rats, which is consistent with the enhanced effects reported in hypertension. Furthermore, this vasorelaxant effect was completely blocked when a $\mathrm{CB}_{1}$ antagonist was used prior to the addition of $\mathrm{ACPA}$, indicating that the vasorelaxant effect relies on the activation of $\mathrm{CB}_{1}$ receptors suggesting a mechanism similar to that reported for healthy rats [7].

The modulation of $\mathrm{CB}_{1}$ receptors has already been reported in some diseases. During hyperglycemia, the expression of $\mathrm{CB}_{1}$ receptors in the frontal cortex of mice is reduced [22], but they are overexpressed in the kidney, pancreas and nervous system [2,4,5]. In addition, $\mathrm{CB}_{1}$ receptors are overexpressed in the vasculature of hypertensive rats, which is related to the increased vasorelaxant effect caused by cannabinoids [13,19]. Therefore, in order to evaluate the possible changes in $\mathrm{CB}_{1}$ expression in the aortas of diabetic rats, we analyzed total $\mathrm{CB}_{1}$ receptor expression and phosphorylated $\mathrm{CB}_{1}$ receptors by confocal microscopy. Our results show that $\mathrm{CB}_{1}$ receptors are expressed at higher levels on aortic rings from diabetic rats compared to those from healthy rats. Thus, the enhanced vasorelaxant effect induced by ACPA in diabetic rats could be explained by the overexpression of $\mathrm{CB}_{1}$ receptors on aortic smooth muscle cells. These findings agree with previous studies in other tissues [2]. The vasorelaxant effect increases after eight weeks of diabetes induction, which is consistent with $\mathrm{CB}_{1}$ receptor overexpression after eight weeks. This overexpression could be relevant in other intracellular signaling pathways, as $\mathrm{CB}_{1}$ activation has also been reported to contribute to vascular inflammation $[23,24]$, induce cell death in human coronary artery endothelial cells [25] and promote atherosclerosis [26]. On the other hand, $\mathrm{CB}_{1}$ receptor phosphorylation at serine 316 has been reported to reduce the receptor effects $[5,27]$. This increase in phosphorylated $\mathrm{CB}_{1}$ receptors could represent a compensatory mechanism for the increase in total $\mathrm{CB}_{1}$ receptor expression. Although phosphorylated $\mathrm{CB}_{1}$ receptors increase from week 4 to 8 , a significant increase in the vasorelaxant effect of ACPA on aortic rings from diabetic rats was observed at eight weeks, indicating that this compensatory response did not affect the activation of $\mathrm{CB}_{1}$ receptors in our study.

Our results also show that aortic rings from diabetic rats have decreased reactivity to phenylephrine, which was determined previously in other studies [28] and may be related to a decrease in the expression of $\alpha$-adrenergic receptors associated with high glucosuria [29].

In our earlier study, we showed that $A C P A$ activation of $\mathrm{CB}_{1}$ in smooth muscle results in vasorelaxation of aortic rings in healthy rats [7], and in the current study, we link diabetes to greater vasorelaxation of aortic rings. Thus, the current findings add to a suggestive picture of the interaction between diabetes, $\mathrm{CB}_{1}$ and cardiovascular responses, suggesting that upregulation of the endocannabinoid system may positively alter vascular function. Previous studies have suggested that activation of $\mathrm{CB}_{1}$ is involved in the development of cardiovascular complications of diabetes [10]. Our results suggest that diabetes per se may increase total $C_{1} B_{1}$ receptor expression and phosphorylated $\mathrm{CB}_{1}$ receptors in aortic rings and indicate a potential target for vascular complications in experimental diabetes [12,30], as it has been proposed for other disorders associated with type 2 diabetes mellitus [31]. Recent studies have shown the potential therapeutic role of the endocannabinoid system in diabetes complications, including the treatment of diabetic nephropathy [32].

Further studies are needed to elucidate other possible implications of $\mathrm{CB}_{1}$ receptor overexpression in the aorta in diabetes and its influence on the progression of the cardiovascular complications of this metabolic disease. 


\section{Materials and Methods}

\subsection{Animals}

Male Wistar rats (approximately 2 months old, weight 230-350 g) were randomly divided into groups, one of healthy rats and one to undergo experimentally induced diabetes. All animals were maintained under the same conditions at the laboratory animal facility of the Centro Universitario de Investigaciones Biomédicas at Universidad de Colima, México. The rats were housed under standard light/dark conditions (12 h light/12 h dark) at $22 \pm 2{ }^{\circ} \mathrm{C}$. They were fed ad libitum with water and rodent food (Envigo Labs Corporation, Indianapolis, IN, USA). We conducted all experiments and animal management protocols in accordance with the ethical standards of the Mexican Official Norm technical specifications for the production, care and use of laboratory animals (NOM-062-ZOO-1999) and recommendations listed in the Guide for the Care and Use of Laboratory Animals from the United States National Institutes of Health.

\subsection{Experimental Induction of Diabetes}

We induced diabetes in rats by a single intraperitoneal injection of $45 \mathrm{mg}$ of STZ (Sigma-Aldrich, St. Louis, MO, USA) per kilogram of body weight [33]. STZ damages the pancreatic $\beta$ cells, affecting serum glucose. Fasting blood glucose $\geq 200 \mathrm{mg} / \mathrm{dL}$ was used to confirm a diabetic state [33].

\subsection{Cannabinoid Administration}

ACPA (Tocris, Bristol, UK) was dissolved in Tocrisolve and used at $30 \mu \mathrm{M}$ as described in a previous in vitro study [7].

\subsection{Glucose Measurements}

We measured glucose parameters after $12 \mathrm{~h}$ of overnight fasting, as described previously [34].

\subsection{Removal and Preparation of Aortas}

Diabetic and healthy male Wistar rats were anesthetized and euthanized by intraperitoneal administration of pentobarbital. The aorta was removed via an incision in the thoracic cavity and placed on a Petri dish with Krebs-Henseleit solution (118 mM NaCl, $5 \mathrm{mM} \mathrm{KCl,} 1.2 \mathrm{mM} \mathrm{MgSO}$, $1.2 \mathrm{mM} \mathrm{KH}_{2} \mathrm{PO}_{4}, 25 \mathrm{mM} \mathrm{NaHCO}, 2 \mathrm{mM} \mathrm{CaCl}_{2}, 2 \mathrm{~g}$ of D-glucose; $\mathrm{pH}$ 7.4). Aortas were fixed with $4 \%$ paraformaldehyde for $24 \mathrm{~h}$ for immunohistochemical experiments or cut into $3 \mu \mathrm{m}$ rings for tension recordings.

\subsection{Aortic Ring Tension Recordings}

Aortic rings were placed in a $10 \mathrm{~mL}$ tissue bath filled with Krebs-Henseleit solution, bubbled with $95 \% \mathrm{O}_{2}$ and $5 \% \mathrm{CO}_{2}$ and maintained at $37{ }^{\circ} \mathrm{C}$ in a circulating water bath. The rings were placed between two stainless steel wires; one wire was fixed to a manipulator, and the other was connected to an isometric force transducer (Radnoti Glass Technology Inc., Monrovia, CA, USA). The force transducer was connected to a CyberAmp (Axon Instruments, Foster City, CA, USA) and the signal acquired with a Digidata 1200 (Axon Instruments, Foster City, CA, USA) in the Axoscope subroutine of pClamp (version 9; Axon Instruments, Foster City, CA, USA). Aortic rings were precontracted with $1 \mu \mathrm{M}$ phenylephrine and, when contraction was stable (this was set at $100 \%$ ), we added $30 \mu \mathrm{M}$ ACPA to the bath. We performed analyses using the Clampfit subroutine. The experiments were performed in duplicate, and the data averaged. Results are expressed as the mean \pm standard error of the measurements from at least 8 aorta rings from at least four different rats. 


\subsection{Immunohistochemical Analysis of Aortic Rings}

After fixation in paraformaldehyde, the aorta was embedded in paraffin and cut into 3- $\mu \mathrm{m}$ aortic rings, which were placed on glass slides. The slides were washed three times with xylene for 10 min each (Sigma-Aldrich, St. Louis, MO, USA). We then rehydrated the rings by washing for 3 min with decreasing concentrations of ethanol (95\%, 70\%,50\% and 30\%; three times each). Next, the rings were incubated in 10\% normal goat serum in phosphate-buffered saline (PBS)/0.2\% Triton X-100 for $30 \mathrm{~min}$ at room temperature to block background staining and permeabilize the cells. After being blocked, the rings were incubated overnight at $4{ }^{\circ} \mathrm{C}$ with anticannabinoid receptor I antibody (1:100; cat. no. ab23703, Abcam, Cambridge, MA, USA) or recombinant anticannabinoid receptor I (phospho S316) antibody [EPR2223(N)] (1:100; cat. no. ab186428, Abcam, Cambridge, MA, USA) and anti-alpha smooth muscle actin [1A4] antibody (1:50; cat. no. ab7817, Abcam, Cambridge, MA, USA). The next day, we washed the slides in PBS with $0.2 \%$ Triton X-100 and $1 \%$ normal goat serum three times for 5 min each. Secondary antibodies (1:100 FITC-conjugated anti-rabbit antibody (1:100; cat. no. ab6717, Abcam, Cambridge, MA, USA) and 1:50 goat anti-mouse IgG (H+L) cross-adsorbed secondary antibody, Alexa Fluor 568 (cat. no. A-11004, Thermo Fisher Scientific, Waltham, MA, USA) were added to the aortic rings, which we then incubated for $1 \mathrm{~h}$ in the dark at room temperature. Finally, we washed the slides three times in PBS and mounted coverslips using ProLong Gold Antifade reagent with DAPI (Thermo Fisher Scientific, Waltham, MA, USA). The specificity of the antibodies was evaluated by performing experiments in the absence of the first antibodies and by pre-absorbing the cannabinoid receptor I antibody with its blocking peptide (cat. \# ab50542, Abcam, Cambridge, MA, USA) 30 min prior to addition to the samples.

We acquired confocal images using an LSM700 Zeiss confocal microscope using a 40× objective with a numeric aperture of 1.3. The mean intensity of the immunofluorescence of 10 different images from four different experiments was calculated using ImageJ software (National Institutes of Health, Bethesda, MD, USA) [35].

\subsection{Statistical Analysis}

We performed descriptive statistical analyses using Stata software (version 11). Variables are reported as mean and standard error. We used paired Student's $t$-tests to assess differences in mean values at the beginning and end of each intervention and Student's $t$-tests for independent samples to assess differences in the mean values recorded for rats with experimentally induced diabetes vs. control rats. Analysis of variance (ANOVA) was used to assess differences between groups. Significance was considered when $p<0.05$.

Author Contributions: Conceived and designed the experiments, contributed with new methods: M.H., M.R.-S., E.S.-P., X.T., and O.N.-S. Performed research and analyzed data: E.S.-P., C.R.-F., Z.U., F.A., E.C., and Y.C. Wrote the paper: E.S.-P., X.T., M.R.-S., and M.H. All authors have read and agreed to the published version of the manuscript.

Funding: This work was partially financed by CONACyT-México (Grant \#152773).

Conflicts of Interest: The authors declare no conflict of interest.

\section{References}

1. Cristino, L.; Becker, T.; Di Marzo, V. Endocannabinoids and energy homeostasis: An update. BioFactors 2014, 40, 389-397. [CrossRef] [PubMed]

2. Vilches-Flores, A.; Delgado-Buenrostro, N.L.; Navarrete-Vázquez, G.; Villalobos-Molina, R. CB1 cannabinoid receptor expression is regulated by glucose and feeding in rat pancreatic islets. Regul. Pept. 2010, 163, 81-87. [CrossRef]

3. Sidibeh, C.O.; Pereira, M.J.; Lau Börjesson, J.; Kamble, P.G.; Skrtic, S.; Katsogiannos, P.; Sundbom, M.; Svensson, M.K.; Eriksson, J.W. Role of cannabinoid receptor 1 in human adipose tissue for lipolysis regulation and insulin resistance. Endocrine 2017, 55, 839-852. [CrossRef] [PubMed] 
4. Jenkin, K.A.; Mcainch, A.J.; Zhang, Y.; Kelly, D.J.; Hryciw, D.H. Elevated cannabinoid receptor 1 and G protein-coupled receptor 55 expression in proximal tubule cells and whole kidney exposed to diabetic conditions. Clin. Exp. Pharmacol. Physiol. 2015, 42, 256-262. [CrossRef]

5. Díaz-Asensio, C.; Setién, R.; Echevarría, E.; Casis, L.; Casis, E.; Garrido, A.; Casis, O. Type 1 diabetes alters brain cannabinoid receptor expression and phosphorylation status in rats. Horm. Metab. Res. 2008, 40, 454-458. [CrossRef] [PubMed]

6. Dannert, M.T.; Alsasua, A.; Herradon, E.; Martín, M.I.; López-Miranda, V. Vasorelaxant effect of Win 55,212-2 in rat aorta: New mechanisms involved. Vascul. Pharmacol. 2007, 46, 16-23. [CrossRef] [PubMed]

7. Sánchez-Pastor, E.; Andrade, F.; Sánchez-Pastor, J.M.; Elizalde, A.; Huerta, M.; Virgen-Ortiz, A.; Trujillo, X.; Rodríguez-Hernández, A. Cannabinoid receptor type 1 activation by arachidonylcyclopropylamide in rat aortic rings causes vasorelaxation involving calcium-activated potassium channel subunit alpha- 1 and calcium channel, voltage-dependent, L type, alpha 1C subunit. Eur. J. Pharmacol. 2014, 729, 100-106. [CrossRef]

8. Hillard, C.J. Endocannabinoids and vascular function. J. Pharmacol. Exp. Ther. 2000, 294, 27-32. [PubMed]

9. Randall, M.D.; Kendall, D.A.; O'Sullivan, S. The complexities of the cardiovascular actions of cannabinoids. Br. J. Pharmacol. 2004, 142, 20-26. [CrossRef]

10. Gruden, G.; Barutta, F.; Kunos, G.; Pacher, P. Role of the endocannabinoid system in diabetes and diabetic complications. Br. J. Pharmacol. 2016, 173, 1116-1127. [CrossRef]

11. Horvth, B.; Mukhopadhyay, P.; Hask, G.; Pacher, P. The endocannabinoid system and plant-derived cannabinoids in diabetes and diabetic complications. Am. J. Pathol. 2012, 180, 432-442. [CrossRef] [PubMed]

12. Altinok, A.; Cokun, Z.M.; Karaolu, K.; Bolkent, S.; Akkan, A.G.; zyazgan, S. $\Delta$ 9-tetrahydrocannabinol treatment improved endothelium-dependent relaxation on streptozotocin/nicotinamide-induced diabetic rat aorta. Acta Physiol. Hung. 2015, 102, 51-59. [CrossRef] [PubMed]

13. Bátkai, S.; Pacher, P.; Osei-Hyiaman, D.; Radaeva, S.; Liu, J.; Harvey-White, J.; Offertáler, L.; Mackie, K.; Rudd, M.A.; Bukoski, R.D.; et al. Endocannabinoids acting at cannabinoid-1 receptors regulate cardiovascular function in hypertension. Circulation 2004, 110, 1996-2002. [CrossRef] [PubMed]

14. Wang, Y.; Kaminski, N.E.; Wang, D.H. VR1-mediated depressor effects during high-salt intake: Role of anandamide. Hypertension 2005, 46, 986-991. [CrossRef]

15. Stanley, C.P.; Wheal, A.J.; Randall, M.D.; O'Sullivan, S.E. Cannabinoids alter endothelial function in the Zucker rat model of type 2 diabetes. Eur. J. Pharmacol. 2013, 720, 376-382. [CrossRef]

16. Li, J.; Kaminski, N.E.; Wang, D.H. Anandamide-induced depressor effect in spontaneously hypertensive rats: Role of the vanilloid receptor. Hypertension 2003, 41, 757-762. [CrossRef]

17. Wheal, A.J.; Bennett, T.; Randall, M.D.; Gardiner, S.M. Cardiovascular effects of cannabinoids in conscious spontaneously hypertensive rats. Br. J. Pharmacol. 2007, 152, 717-724. [CrossRef]

18. Wheal, A.J.; Randall, M.D. Effects of hypertension on vasorelaxation to endocannabinoids in vitro. Eur. J. Pharmacol. 2009, 603, 79-85. [CrossRef]

19. Guo, Z.; Liu, Y.X.; Yuan, F.; Ma, H.J.; Maslov, L.; Zhang, Y. Enhanced vasorelaxation effect of endogenous anandamide on thoracic aorta in renal vascular hypertension rats. Clin. Exp. Pharmacol. Physiol. 2015, 42, 950-955. [CrossRef]

20. Matias, I.; Gonthier, M.P.; Orlando, P.; Martiadis, V.; De Petrocellis, L.; Cervino, C.; Petrosino, S.; Hoareau, L.; Festy, F.; Pasquali, R.; et al. Regulation, function, and dysregulation of endocannabinoids in models of adipose and $\beta$-pancreatic cells and in obesity and hyperglycemia. J. Clin. Endocrinol. Metab. 2006, 91, 3171-3180. [CrossRef]

21. Hopps, J.J.; Dunn, W.R.; Randall, M.D. Enhanced vasorelaxant effects of the endocannabinoid-like mediator, oleamide, in hypertension. Eur. J. Pharmacol. 2012, 684, 102-107. [CrossRef] [PubMed]

22. Moura, L.I.F.; Lemos, C.; Ledent, C.; Carvalho, E.; Köfalvi, A. Chronic insulinopenia/hyperglycemia decreases cannabinoid CB 1 receptor density and impairs glucose uptake in the mouse forebrain. Brain Res. Bull. 2019, 47, 101-109. [CrossRef] [PubMed]

23. El-Remessy, A.B.; Rajesh, M.; Mukhopadhyay, P.; Horváth, B.; Patel, V.; Al-Gayyar, M.M.H.; Pillai, B.A.; Pacher, P. Cannabinoid 1 receptor activation contributes to vascular inflammation and cell death in a mouse model of diabetic retinopathy and a human retinal cell line. Diabetologia. 2011, 54, 1567-1578. [CrossRef] [PubMed] 
24. Gestrich, C.; Duerr, G.D.; Heinemann, J.C.; Meertz, A.; Probst, C.; Roell, W.; Schiller, W.; Zimmer, A.; Bindila, L.; Lutz, B.; et al. Activation of endocannabinoid system is associated with persistent inflammation in human aortic aneurysm. BioMed Res. Int. 2015, 2015, 456582. [CrossRef] [PubMed]

25. Rajesh, M.; Mukhopadhyay, P.; Haskó, G.; Liaudet, L.; MacKie, K.; Pacher, P. Cannabinoid-1 receptor activation induces reactive oxygen species-dependent and -independent mitogen-activated protein kinase activation and cell death in human coronary artery endothelial cells. Br. J. Pharmacol. 2010, 160, 688-700. [CrossRef] [PubMed]

26. Guillamat-Prats, R.; Rami, M.; Herzig, S.; Steffens, S. Endocannabinoid signalling in atherosclerosis and related metabolic complications. Thromb. Haemost. 2019, 119, 567-575. [CrossRef]

27. Garcia, D.E.; Brown, S.; Hille, B.; Mackie, K. Protein kinase C disrupts cannabinoid actions by phosphorylation of the CB1 cannabinoid receptor. J. Neurosci. 1998. [CrossRef]

28. Saleh, D.O.; Bayoumi, A.R.; El-Eraky, W.I.; El-Khatib, A.S. Streptozotocin-induced vascular and biochemical changes in rats: Effects of rosiglitazone vs. metformin. Bull. Fac. Pharm. 2013, 51, 131-138. [CrossRef]

29. Bucci, M.; Roviezzo, F.; Brancaleone, V.; Lin, M.I.; Di Lorenzo, A.; Cicala, C.; Pinto, A.; Sessa, W.C.; Farneti, S.; Fiorucci, S.; et al. Diabetic mouse angiopathy is linked to progressive sympathetic receptor deletion coupled to an enhanced caveolin-1 expression. Arterioscler. Thromb. Vasc. Biol. 2004, 24, 721-726. [CrossRef]

30. Vella, R.K.; Jackson, D.J.; Fenning, A.S. $\Delta$ 9-tetrahydrocannabinol prevents cardiovascular dysfunction in STZ-diabetic Wistar-Kyoto rats. BioMed Res. Int. 2017, 2027, 7974149. [CrossRef]

31. Nagappan, A.; Shin, J.; Jung, M.H. Role of cannabinoid receptor type 1 in insulin resistance and its biological implications. Int. J. Mol. Sci. 2019, 20, 2109. [CrossRef]

32. Barutta, F.; Grimaldi, S.; Gambino, R.; Vemuri, K.; Makriyannis, A.; Annaratone, L.; Di Marzo, V.; Bruno, G.; Gruden, G. Dual therapy targeting the endocannabinoid system prevents experimental diabetic nephropathy. Nephrol. Dial. Transplant. 2017, 32, 1655-1665. [CrossRef] [PubMed]

33. Márquez-Ibarra, A.; Huerta, M.; Villalpando-Hernández, S.; Ríos-Silva, M.; Díz-Reval, M.I.; Cruzblanca, H.; Mancilla, E.; Trujillo, X. The effects of dietary iron and capsaicin on hemoglobin, blood glucose, insulin tolerance, cholesterol, and triglycerides, in Healthy and diabetic Wistar rats. PLoS ONE 2016, 1, e0152625. [CrossRef] [PubMed]

34. Miron, V.R.; Bauermann, L.; Morsch, A.L.B.; Zanin, R.F.; Corrêa, M.; Silva, A.C.; Mazzanti, C.; Morsch, V.M.; Lunkes, G.I.; Schetinger, M.R.C. Enhanced NTPDase and 5'-nucleotidase activities in diabetes mellitus and iron-overload model. Mol. Cell. Biochem. 2007, 298, 101-107. [CrossRef]

35. Abràmoff, M.D.; Magalhães, P.J.; Ram, S.J. Image processing with image. J. Biophotonics Int. 2004, 11, 36-42.

Publisher's Note: MDPI stays neutral with regard to jurisdictional claims in published maps and institutional affiliations.

(C) 2020 by the authors. Licensee MDPI, Basel, Switzerland. This article is an open access article distributed under the terms and conditions of the Creative Commons Attribution (CC BY) license (http://creativecommons.org/licenses/by/4.0/). 